\title{
Influence of ageing heat treatment on alloy A-286 microstructure and stress corrosion cracking behaviour in PWR primary water
}

\author{
M. Savoie ${ }^{a, b}$, C. Esnouf ${ }^{c}$, L. Fournier ${ }^{a}$, D. Delafosse ${ }^{b, *}$ \\ ${ }^{a}$ Commissariat à l'Energie Atomique, CEA Saclay \\ DMN/SEMI/LCMI, 91191 Gif-Sur-Yvette, France \\ ${ }^{\mathrm{b}}$ Ecole Nationale des Mines de Saint-Etienne, Centre Science des Matériaux et des \\ Structures, UMR CNRS 5146, 158 cours Fauriel, 42023 Saint-Etienne Cedex 02 , France \\ ' Groupe d'Etude de Metallurgie Physique et de Physique des Matériaux, INSA Lyon, \\ 69621 Villeurbanne, France
}

\begin{abstract}
The influence of ageing heat treatment on alloy A-286 microstructure and stress corrosion cracking behaviour in simulated Pressurized Water Reactor (PWR) primary water was investigated. A-286 microstructure was characterized by transmission electron microscopy for ageing heat treatment at $670^{\circ} \mathrm{C}$ and $720^{\circ} \mathrm{C}$ for duration ranging from $5 \mathrm{~h}$ to $100 \mathrm{~h}$. Spherical $\gamma^{\prime}$ phase with mean diameters ranging from 4.6 to $9.6 \mathrm{~nm}$ and densities ranging from $8.5 \times 10^{22} \mathrm{~m}^{-3}$ to $2 \times 10^{23} \mathrm{~m}^{-3}$ were measured. Results suggest that both $\gamma^{\prime}$ phase mean diameter and density quickly saturate with time for ageing heat treatment at $720^{\circ} \mathrm{C}$ while $\gamma^{\prime}$ mean diameter increase significantly up to $100 \mathrm{~h}$ for ageing heat treatment at $670^{\circ} \mathrm{C}$. Grain boundary $\eta$ phase precipitates were systematically observed for ageing heat treatment at $720^{\circ} \mathrm{C}$ even for short ageing period. In contrast, no grain boundary $\eta$ phase precipitates were observed for ageing heat treatment at $670^{\circ} \mathrm{C}$ except after $100 \mathrm{~h}$. Hardening by $\gamma$ ' precipitation was well described by the dispersed barrier hardening model with a $\gamma^{\prime}$ barrier strength of 0.23 . Stress corrosion cracking behaviour of A-286 was investigated by means of constant elongation rate tensile tests at $1.5 \times 10^{-7} \mathrm{~s}^{-1}$ in simulated PWR primary water at $320^{\circ} \mathrm{C}$ and $360^{\circ} \mathrm{C}$. In all cases, initiation was transgranular while propagation was intergranular. Grain boundary $\eta$ phase precipitates were found to have no significant effect on stress corrosion cracking. In contrast, yield strength and to a lesser extend temperature were found to have significant influences on A-286 susceptibility to stress corrosion cracking.
\end{abstract}




\footnotetext{
* Corresponding author. Tel.: +33-4-77-42-02-98; fax: +33-4-77-42-01-57;

E-mail address: david.delafosse@emse.fr
}

\section{Introduction}

Precipitation-hardening austenitic stainless steel A-286 is widely used in the gas turbine industry for its high strength and corrosion resistance. Since it also has a thermal coefficient of expansion comparable to type $304 \mathrm{SS}$, it is also used for reactor vessel internals bolting applications in the nuclear industry [1]. Several A-286 reactor vessel internals bolts failures were reported during PWR in-service inspections in the early 80's [1-2]. The subsequent extensive evaluation program identified Intergranular Stress Corrosion Cracking (IGSCC) as the degradation mechanism and recommended to operate bolts at stress levels below the material's yield stress [1-2]. However, the effect of heat treatment and metallurgical structure on IGSCC as received little attention for A-286 in comparison to other precipitationhardening NiFeCr alloys 718 and X-750 also used in the nuclear industry for bolts, springs, beams and pins applications [3-4]. The aim of this study was therefore to gain insights into the influence of microstructure on A-286 SCC behaviour in simulated PWR primary water. A-286 is strengthened by the ordered fcc $\gamma^{\prime} \mathrm{Ni}_{3}(\mathrm{Ti}, \mathrm{Al})$ phase [5]. However it is also susceptible to the formation of the stable HCP $\eta \mathrm{Ni}_{3} \mathrm{Ti}$ phase depending on the ageing heat treatment. The effect of ageing heat treatment at $670^{\circ} \mathrm{C}$ and $720^{\circ} \mathrm{C}$ for duration ranging from 5h to $100 \mathrm{~h}$ on both $\gamma^{\prime}$ and $\eta$ phase precipitation was therefore first carefully investigated by Transmission Electron Microscopy (TEM). On the basis of these results the effect of the same ageing heat treatment on A-286 SCC susceptibility was studied by means of constant elongation rate tensile (CERT) tests in simulated PWR primary water at $320^{\circ} \mathrm{C}$ and $360^{\circ} \mathrm{C}$.

\section{Experimental procedure}

The chemical composition of the A-286 used in this work is given in Table 1. All specimens were machined out of a $12.5 \mathrm{~mm}$ diameter rod provided by UGITECH. Prior to ageing, all 
specimens were encapsulated under primary vacuum in quartz tubes and solution annealed at $930^{\circ} \mathrm{C}$ for $1 \mathrm{~h}$ and water quenched.

Grain size was determined after mechanical polishing with wet $\mathrm{SiC}$ abrasive paper down to $1 \mu \mathrm{m}$ roughness and chemical etching in a $30 \mathrm{cc} \mathrm{HCl}, 30 \mathrm{cc} \mathrm{HNO}_{3}, 20 \mathrm{cc} \mathrm{CH}_{3} \mathrm{COOH}$ and $20 \mathrm{cc}$ $\mathrm{H}_{2} \mathrm{O}$ solution for 30s. An average grain size of $6 \mu \mathrm{m}$ was measured.

TEM thin foils were prepared using a Tenupol twin jet electropolishing unit with a 70\% ethanol, $20 \%$ n-butyl alcohol and $10 \%$ perchloric acid electrolyte at $-20^{\circ} \mathrm{C}$ and $70 \mathrm{~V}$. Microstructures were characterised using a Tecnai FEI transmission electron microscope operating at $300 \mathrm{kV}$ and equipped with a Gatan CCD digital camera. $\gamma$ ' precipitates were imaged by means of the dark field technique using a $5 \mu \mathrm{m}$ diameter objective aperture and the superlattice reflexion $(100)_{\gamma}$, of the $<110>$ zone axis. Thin foil thickness were determined using thickness fringes along a grain boundary.

Smooth tensile test specimens with a $4 \mathrm{~mm}$ diameter and a $36 \mathrm{~mm}$ gauge length were used for SCC testing. All specimens were mechanically polished with SiC paper down to grit 4000 and rinsed with ethanol prior to SCC testing. In order to determine the effect of the cold-worked layer created by mechanical polishing on A-286 SCC behaviour, a unique specimen was also electropolished at $10 \mathrm{~V}$ during $1 \mathrm{~min}$ with a $45 \%$ methanol, $45 \% n$-butyl alcohol and 10\% perchloric acid solution at room temperature. CERT tests were performed at $1.5 \times 10^{-7} \mathrm{~s}^{-1}$ in simulated PWR primary water (1000 ppm of boric acid and $2 \mathrm{ppm}$ of lithium hydroxide) at $320^{\circ} \mathrm{C}$ and $360^{\circ} \mathrm{C}$ in a 0.881 austenitic stainless steel static autoclave. All tests were conducted with a $30 \mathrm{cc} / \mathrm{kg} \mathrm{H} \mathrm{H}_{2} \mathrm{O}$ dissolved hydrogen concentration controlled with a $\mathrm{Pd} / \mathrm{Ag}$ probe. Obtained engineering stress-strain curves were post-processed by linearly fitting the elastic part to a Young's modulus of $200 \mathrm{GPa}$. Analysis of both the fracture and the side surfaces of specimens after CERT testing was carried out using a Field Emission Gun (FEG) Scanning Electron Microscope (SEM). Prior to SEM examination specimens were ultrasonically cleaned first for $2 \mathrm{~h}$ in a $20 \mathrm{cc}$ chlorydric acid and $80 \mathrm{cc}$ water solution with $2 \mathrm{~g}$ hexamethylenetetramine and then in acetone for 5 minutes in order to remove the oxide layer formed during CERT testing in high temperature water. 


\section{Results}

\subsection{Microstructure}

As mentioned earlier $\gamma^{\prime}$ and $\eta$ phase precipitation for ageing heat treatment at $670^{\circ} \mathrm{C}$ and $720^{\circ} \mathrm{C}$ up to $100 \mathrm{~h}$ was first carefully investigated by TEM in this study. Results of this characterisation are described here.

\section{y'phase:}

The $\gamma^{\prime}$ mean diameter, volume fraction and density measured after ageing for 50 and $100 \mathrm{~h}$ at $670^{\circ} \mathrm{C}$, and 5, 16, 24 and $100 \mathrm{~h}$ at $720^{\circ} \mathrm{C}$ are summarized in Table 2. Between 192 and 1066 precipitates in 3 to 5 different areas of a single TEM foil were analysed for each ageing condition. Thin foils thickness ranged between 30 and $110 \mathrm{~nm}$. A dark-field TEM micrograph of $\gamma^{\prime}$ precipitation for the $16 \mathrm{~h}$ at $720^{\circ} \mathrm{C}$ ageing heat treatment is displayed in Figure 1. Size distribution histograms for $\gamma^{\prime}$ precipitates are displayed in Figure 2 for all ageing heat treatment investigated. It should be mentioned here that $\gamma^{\prime}$ were too small to be imaged by TEM for ageing at $670^{\circ} \mathrm{C}$ for $24 \mathrm{~h}$. The evolution of the $\gamma^{\prime}$ density and mean diameter as a function of ageing time are shown in Figure 3 and 4, respectively.

Mean diameters are ranging from 4.6 to $9.6 \mathrm{~nm}$. The mean diameter is increasing with short ageing time at $720^{\circ} \mathrm{C}$, reaches a maximum at $16 \mathrm{~h}$, then decrease for $24 \mathrm{~h}$ and seems to saturate for ageing time up to $100 \mathrm{~h}$. In contrast, mean diameter is still increasing with ageing time up to $100 \mathrm{~h}$ at $670^{\circ} \mathrm{C}$. The mean diameter measured in this study after ageing at $720^{\circ} \mathrm{C}$ for $5 \mathrm{~h}$ is consistent with the value reported by Thompson [6] for a slightly higher ageing duration at the same temperature. The mean diameter measured in this study after ageing at $720^{\circ} \mathrm{C}$ for $16 \mathrm{~h}$ is also in excellent agreement with the values reported by Thompson [6] and De Cicco [7] for the same ageing conditions.

Densities are ranging from $8.5 \times 10^{22} \mathrm{~m}^{-3}$ to $2 \times 10^{23} \mathrm{~m}^{-3}$. Density seems to saturate around $10^{23} \mathrm{~m}^{-3}$ to $2 \times 10^{23} \mathrm{~m}^{-3}$ for ageing time at both $670^{\circ} \mathrm{C}$ and $720^{\circ} \mathrm{C}$.

\section{n phase:}

The results of $\eta$ phase TEM observations after ageing for 24,50 and $100 \mathrm{~h}$ at $670^{\circ} \mathrm{C}$, and 5 , 16,24 and $100 \mathrm{~h}$ at $720^{\circ} \mathrm{C}$ are summarized in Table 3. About 100 grain boundaries in 2 different TEM foils were observed for each ageing condition. As illustrated in Figure 5, $\eta$ 
phase in the form of discs or platelets were found to decorate grain boundaries. The fraction of grain boundaries decorated by $\eta$ phase is displayed in Table 3 making a distinction between grain boundaries with disc $\eta$ phase and grain boundaries with platelets $\eta$ phase. In good agreement with results from Brooks et al. [8], grain boundary $\eta$ phase precipitates were systematically observed for ageing heat treatment at $720^{\circ} \mathrm{C}$ even for short ageing period. In contrast, no grain boundary $\eta$ phase precipitates were observed for ageing heat treatment at $670^{\circ} \mathrm{C}$ except after $100 \mathrm{~h}$ ageing.

\subsection{Precipitation-induced hardening}

Precipitation-induced hardening was calculated by subtracting the yield stress value measured for solution annealed A-286 during tensile testing at $360^{\circ} \mathrm{C}$ from the yield stress value measured after CERT testing at $1.5 \times 10^{-7} \mathrm{~s}^{-1}$ in simulated primary water at $360^{\circ} \mathrm{C}$ for ageing heat treatment at $670^{\circ} \mathrm{C}$ for $50 \mathrm{~h}$ and $100 \mathrm{~h}$ and at $720^{\circ} \mathrm{C}$ for $16 \mathrm{~h}$ and $100 \mathrm{~h}$. These calculated precipitation-induced increments in yield stress $(\Delta \sigma)$ are listed in Table 4 together with the mean diameter and density reported in the previous section for the corresponding ageing heat treatment. $\Delta \sigma$ and $\gamma^{\prime}$ precipitate sizes and densities were used to calculate $\gamma^{\prime}$ barrier strength using the dispersed barrier hardening model:

$$
\Delta \sigma=\operatorname{Ma} \mu \mathrm{b}(\mathrm{Nd})^{1 / 2}
$$

where $\Delta \sigma$ is the yield strength increase, M is the Taylor factor (3.06 for FCC metals [9]), $\alpha$ is the barrier strength, $\mu$ is the shear modulus (75.8 GPa for A-286 alloy [10]), $b$ is the Burgers vector $(0.25 \mathrm{~nm}), \mathrm{N}$ is the barrier density and $\mathrm{d}$ is the barrier size. $\gamma^{\prime}$ barrier strength values calculated for ageing heat treatment at $670^{\circ} \mathrm{C}$ for $50 \mathrm{~h}$ and $100 \mathrm{~h}$ and at $720^{\circ} \mathrm{C}$ for $16 \mathrm{~h}$ and 100h are listed in Table 4. All values are in good agreement and lie around 0.23.

\subsection{Stress corrosion cracking}

The results of the CERT tests performed in simulated PWR primary water at 320 and $360^{\circ} \mathrm{C}$ on specimens aged at $670^{\circ} \mathrm{C}$ for $24 \mathrm{~h}, 50 \mathrm{~h}$ and $100 \mathrm{~h}$ and at $720^{\circ} \mathrm{C}$ for $16 \mathrm{~h}$ and $100 \mathrm{~h}$ are summarized in Tables 5 and 6 . The yield strength, ultimate tensile strength, strain to failure, 
percentage of "brittle" cracking on fracture surface, total crack length, and the ratio of total crack length to failure strain are tabulated for each specimen. SEM micrographs of the fracture surfaces of specimens aged $50 \mathrm{~h}$ at $670^{\circ} \mathrm{C}$ and $100 \mathrm{~h}$ at $720^{\circ} \mathrm{C}$ and strained in PWR primary water at $320^{\circ} \mathrm{C}$ and $360^{\circ} \mathrm{C}$ are displayed in Figure 6 .

The specimen aged at $670^{\circ} \mathrm{C}$ for $24 \mathrm{~h}$ and strained at $320^{\circ} \mathrm{C}$ in simulated PWR primary water exhibited a fully ductile failure mode. It exhibited the largest strain to failure $(26 \%)$ and did not display any cracks on its side-surface. All the other tested specimens were susceptible to SCC. In all cases, cracks initiated and propagated for a few tens of $\mu \mathrm{m}$ in a transgranular (TG) mode, and then propagated in an intergranular (IG) mode. The possible influence of the cold worked layer resulting from mechanical surface polishing on the TG initiation mode was investigated by means of a specific CERT test in the same conditions on a specimen aged at $720^{\circ} \mathrm{C}$ for $16 \mathrm{~h}$ but that was electropolished before testing. Initiation and first few tens of $\mu \mathrm{m}$ of propagation remained transgranular suggesting that cold worked layer resulting from mechanical surface polishing is not responsible for TG initiation.

Serrations were observed for all conditions of ageing after CERT testing in simulated PWR primary water. It is well known that stainless steels are prone to plastic instabilities due to the Portevin - Le Chatelier (PLC) effect in the temperature and strain rate regime investigated in this study [11-13]. It is also well established that PLC effect domain is a sub-domain of dynamic strain aging (DSA) where the strain rate sensitivity of the flow stress $(\mathrm{SRS}=\Delta \sigma / \Delta \ln \dot{\varepsilon})$ is negative [14-15]. A specific tensile test was therefore performed with a strain rate jump from $1 \times 10^{-4} \mathrm{~s}^{-1}$ to $1.5 \times 10^{-7} \mathrm{~s}^{-1}$ at $6 \%$ of plastic strain at $360^{\circ} \mathrm{C}$ in order to determine the SRS of the flow stress of A-286. A SRS of the flow stress value of -4.25 was measured demonstrating that observed serrations are due to PLC effect. Several authors have recently investigated possible interactions between DSA and PLC effect on environmentally assisted cracking (EAC) phenomena [16-18]. In this work, PLC effect was observed for all specimens strained at $1.5 \times 10^{-7} \mathrm{~s}^{-1}$ independently of the ageing heat treatment while SCC was not observed for all specimens. This suggests that PLC effect does not play a significant role in A-286 SCC behaviour in PWR primary water. 
Test temperature was found to significantly increase A-286 SCC susceptibility in simulated PWR primary water. As already mentioned, the specimen aged at $670^{\circ} \mathrm{C}$ for $24 \mathrm{~h}$ was not susceptible to $\mathrm{SCC}$ at $320^{\circ} \mathrm{C}$. In contrast, the specimen aged in the same condition exhibit $3 \%$ brittle cracking on its fracture surface after CERT testing at $360^{\circ} \mathrm{C}$. For the specimens aged at $670^{\circ} \mathrm{C}$ for $50 \mathrm{~h}$, increasing the temperature from $320^{\circ} \mathrm{C}$ to $360^{\circ} \mathrm{C}$ leads to an increase in the percentage of brittle cracking on the fracture surface from $9 \%$ to $19.5 \%$.

Ageing conditions were also found to have a strong impact, via the yield stress, on A-286 SCC susceptibility in simulated PWR primary water. This effect of the yield strength on SCC is illustrated in Figures 7 and 8. Clearly, an increase in the yield strength results in a significant increase in the susceptibility of the material to SCC. In contrast, grain boundary $\eta$ phase was not found to play a significant role on A-286 SCC.

\section{Discussion}

This study of different ageing heat treatment allows discussion of the effect of yield strength and $\eta$ phase precipitation on A-286 SCC behaviour in simulated PWR primary water.

\subsection{Influence of yield strength}

The evolution of the percentage of brittle cracking on the fracture surface is plotted together the evolution of strain to failure as a function of yield strength in Figure 7. Increasing the yield strength leads to a significant increase in the percentage of brittle cracking on the fracture surface and a concomitant decrease in the strain to failure. The evolution of the ratio of the total crack length over the strain to failure as a function of yield strength is plotted in Figure 8. Again, increasing the yield strength leads to a significant increase in the ratio of the total crack length over the strain to failure. These results clearly demonstrate the important role of the yield strength in the SCC behaviour of A-286 in simulated PWR primary water. This result is in good agreement with the strong influence of yield strength on crack growth rate of stainless steels reported by Andresen et al. [19] in high purity water with 95 and 1580 $\mathrm{ppb}$ of hydrogen at stress intensity factor around $30 \mathrm{MPa} \sqrt{\mathrm{m}}$. 


\subsection{Influence of $\eta$ phase}

Precipitation strengthened alloys are known to be susceptible to coherent hardening phase transformation into HCP phases that may play a detrimental role in EAC phenomena [20]. In precipitation hardened nickel-based alloy 718, $\gamma$ ' transformation into $\delta$ phase is well documented and Miglin et al. [21] correlated an increase in SCC susceptibility in simulated PWR primary water with the presence of grain boundary $\delta$ phase.

The results obtained in this study do not suggest any correlation between the amount of grain boundary coverage by $\eta$ phase and SCC susceptibility. Moreover, as displayed in Table 5, specimens aged at $670^{\circ} \mathrm{C}$ for $50 \mathrm{~h}$ and at $720^{\circ} \mathrm{C}$ for $100 \mathrm{~h}$ exhibit similar yield strength and similar susceptibility to SCC. In contrast, as shown in Table 3, the specimen aged at $670^{\circ} \mathrm{C}$ for $50 \mathrm{~h}$ do not contain any GB $\eta$ phase while the specimen aged at $720^{\circ} \mathrm{C}$ for $100 \mathrm{~h}$ has $80 \%$ of GB decorated with $\eta$ phase, suggesting that $\eta$ phase does not play a significant role in A286 SCC in PWR primary water.

\section{Conclusions}

The influence of ageing heat treatments at $670^{\circ} \mathrm{C}$ and $720^{\circ} \mathrm{C}$ for duration ranging from $5 \mathrm{~h}$ to 100h on A-286 microstructure and its SCC behaviour in simulated PWR primary water was investigated in this study. Results can be summarized as follow:

1. Spherical $\gamma^{\prime}$ precipitation occurs in the early stage of ageing. Ageing at $670^{\circ} \mathrm{C}$ leads to a $\gamma^{\prime}$ precipitates increase in size up to $100 \mathrm{~h}$. In contrast, both $\gamma^{\prime}$ phase size and density quickly saturate after $20 \mathrm{~h}$ of ageing heat treatment at $720^{\circ} \mathrm{C}$.

2. $\gamma^{\prime}$ precipitation induced-hardening is well described using the dispersed barrier hardening model with a $\gamma$ ' strength value of 0.23 .

3. Grain boundary $\eta$ phase precipitation systematically occurs for ageing heat treatment at $720^{\circ} \mathrm{C}$ even for short ageing period. In contrast, no grain boundary $\eta$ phase precipitation occurs for ageing heat treatment at $670^{\circ} \mathrm{C}$ except after $100 \mathrm{~h}$ ageing.

4. A-286 is susceptible to SCC when strained at $1.5 \times 10^{-7} \mathrm{~s}^{-1}$ in PWR primary water at $320^{\circ} \mathrm{C}$ and $360^{\circ} \mathrm{C}$ except after ageing heat treatment at $670^{\circ} \mathrm{C}$ for $24 \mathrm{~h}$ and CERT testing at $320^{\circ} \mathrm{C}$. In all cases, initiation is transgranular while propagation is intergranular. A-286 SCC susceptibility is well correlated with the yield strength. Both the amount of brittle 
cracking on the fracture surface as well as the total crack length on the side surface increase significantly with an increase in yield strength.

5. An increase in the test temperature from $320^{\circ} \mathrm{C}$ to $360^{\circ} \mathrm{C}$ also increases A-286 SCC susceptibility.

6. Grain boundary $\eta$ phase is shown to have no significant detrimental effect on SCC susceptibility of A-286 in simulated PWR primary water.

\section{Acknowledgments}

Financial support was provided by CEA/DSOE-RB. The authors gratefully acknowledge researchers from CEA/SCCME for their help in conducting CERT testing in simulated PWR primary water and researchers from CEA/SRMP for SEM-FEG examinations after SCC testing.

\section{References}

[1] R.S. Piascik and K.E. Moore, Nuclear Technology, 75 (1986) 370-377.

[2] J.B. Hall, S. Fyfitch, and K.E. Moore, Proceedings of the $11^{\text {th }}$ International Conference on Environmental Degradation of Materials in Nuclear Power Systems - Water Reactors, Stevenson, Washington, August 10-14, 2003 (NACE) p. 208.

[3] M.T. Miglin and H.A. Domain, J. Materials Engineering, 92 (1987) 113-132.

[4] I.L.W. Wilson and T.R. Mager, Corrosion, 426 (1986) 352-361.

[5] K. Kusabiraki, Y. Takasawa, T. Ooka, ISIJ International, 355 (1995) 542-547.

[6] A.W. Thompson and J.A. Brooks, Acta metal., 30 (1982) 2197-2203.

[7] H. De Cicco, M.I. Luppo, L.M. Gribaudo, J. Ovejero-Garcia, Materials Characterization, 52 (2004) 85-92.

[8] J.A. Brooks, A.W. Thompson, Metall. Trans., 24A (1993) 1983-1991.

[9] R.E. Stoller, S. J. Zinkle, J. Nucl. Mater., 283-287 (2000) 349-352.

[10] H.M. Ledbetter, W. F. Weston, E.R. Naimon, Journal of Applied Physics, 469 (1975) 3855-3860.

[11] R.W. Hayes and W.C. Hayes, Acta metall., 30 (1982) 1295-1301. 
[12] W. Chen and M.C. Chaturvedi, Mater. Sci. Eng., A229 (1997) 163-168.

[13] A.A. Abduluyahed, K. Rozniatowski and K.J. Kurzydlowski, Scripta Metallurgica et Materialia, 339 (1995) 1489-1492.

[14] L.P. Kubin, Y. Estrin, Acta metall. mater., 385 (1990) 697-708.

[15] A. Van Den Beukel, Acta Metallurgica, 28 (1979) 965-969.

[16] L. Fournier, D. Delafosse, T. Magnin, Mater. Sci. Eng., A316 (2001) 166-173.

[17] V. Garat, J.M. Cloué, B. Viguier, E. Andrieu, Proceedings of the Sixth International Special Emphasis Symposium on Superalloy 718, 625, 706 and Derivatives, Pittsburgh, Pensylvania, October 2-5 (2005).

[18] U. Ehrnsten, M. Ivanchenko, V. Nevdacha, Y. Yagozinskyy, A. Toivonen and H. Hanninen, Proceedings of Eurocorrosion Conference 2004, Nice, September 12-16 (2004).

[19] P.L. Andresen, M.M. Morra, W.C. Catlin, Proceedings of NACE Corrosion 2004, March 28 - April, New Orleans, Louisiana, 2004 (NACE) Paper Nº 04678.

[20] E.E. Brown and D. R. Muzyka, in Superalloys II, (1987) 165-187.

[21] B.P. Miglin, M. T. M., J.V. Monter, T. Sato, K. Aoki, Proceedings of the $4^{\text {th }}$ International Conference on Environmental Degradation of Materials in Nuclear Power Systems - Water Reactors, Jekyll Island, Georgia, August 6-10, 1989 (NACE), p. 11-32. 


\section{LIST OF TABLES}

Table 1: Chemical composition of A-286 (in wt. \%).

Table 2: Summary of $\gamma^{\prime}$ mean diameter, volume fraction and density measurements for A-286 with various ageing heat treatment.

Table 3: Summary of $\eta$ phase TEM observations for A-286 with various ageing heat treatment.

Table 4: Summary of $\gamma^{\prime}$ barrier strength calculated for A-286 with various ageing heat treatment using the dispersed barrier hardening model and $\gamma^{\prime}$ mean diameter and density measured by TEM.

Table 5: Summary of SCC results (YS, UTS, Strain to failure, \% of brittle TG and IG cracking on fracture surface) obtained after CERT testing at $1.5 \times 10^{-7} \mathrm{~s}^{-1}$ in simulated PWR primary water for A-286 with various ageing heat treatment.

Table 6: Summary of SCC results (Total crack length on side surface and total crack length/strain to failure) obtained after CERT testing at $1.5 \times 10^{-7} \mathrm{~s}^{-1}$ in simulated PWR primary water for A-286 with various ageing heat treatment. 


\section{LIST OF FIGURES}

Fig. 1. a) Dark-field TEM micrograph showing $\gamma^{\prime}$ precipitates in the specimen aged $16 \mathrm{~h}$ at $720^{\circ} \mathrm{C}$. The associated diffraction pattern is shown in b). The precipitates were imaged using $(100)_{\gamma}$, superlattice reflexion (indicated by an arrow) in zone axis $<110>$.

Fig. 2. $\gamma^{\prime}$ precipitate size distribution in alloy A-286 aged for (a) $50 \mathrm{~h}$ and (b) $100 \mathrm{~h}$ at $670^{\circ} \mathrm{C}$ and for (c) $5 \mathrm{~h}$, (d) $16 \mathrm{~h}$, (e) $24 \mathrm{~h}$ and (f) $100 \mathrm{~h}$ at $720^{\circ} \mathrm{C}$.

Fig. 3. $\gamma^{\prime}$ density evolution as a function of ageing time at $670^{\circ} \mathrm{C}$ and $720^{\circ} \mathrm{C}$.

Fig. 4. $\gamma^{\prime}$ mean diameter evolution as a function of ageing time at $670^{\circ} \mathrm{C}$ and $720^{\circ} \mathrm{C}$.

Fig. 5. TEM a) dark field micrograph of grain boundary discs $\eta$ phase in A-286 alloy aged 5h at $720^{\circ} \mathrm{C}$ and b) bright field micrograph of grain boundary $\eta$ phase platelets in A-286 aged $16 \mathrm{~h}$ at $720^{\circ} \mathrm{C}$.

Fig. 6. SEM micrographs of the fracture surfaces of specimens aged a)-b) $50 \mathrm{~h}$ at $670^{\circ} \mathrm{C}$ and SCC tested at $360^{\circ} \mathrm{C}$, (c) $100 \mathrm{~h}$ at $720^{\circ} \mathrm{C}$ and SCC tested at $360^{\circ} \mathrm{C}$ and (d) $50 \mathrm{~h}$ at $670^{\circ} \mathrm{C}$ and SCC tested at $320^{\circ} \mathrm{C}$ showing TG initiation and IG propagation.

Fig. 7. Evolution of the percentage of brittle cracking on fracture surface and strain to failure as a function of yield strength in alloy A-286 strained at $1.5 \times 10^{-7} \mathrm{~s}^{-1}$ in PWR primary water at $360^{\circ} \mathrm{C}$. 
Fig. 8. Evolution of the ratio of total crack length on side surface over strain to failure as a function of yield strength in alloy A-286 strained at $1.5 \times 10^{-7} \mathrm{~s}^{-1}$ in PWR primary water at $360^{\circ} \mathrm{C}$. 


\section{Table 1}

\begin{tabular}{lllllllllllllll}
\hline $\mathrm{Fe}$ & $\mathrm{Ni}$ & $\mathrm{Cr}$ & $\mathrm{Ti}$ & $\mathrm{Mn}$ & $\mathrm{Mo}$ & $\mathrm{V}$ & $\mathrm{Al}$ & $\mathrm{Cu}$ & $\mathrm{Si}$ & $\mathrm{Nb}$ & $\mathrm{Co}$ & $\mathrm{C}$ & $\mathrm{P}$ & $\mathrm{S}$ \\
\hline
\end{tabular}

$\begin{array}{lllllllllllllll}\text { Bal. } & 25 & 14.1 & 1.97 & 1.65 & 1.18 & 0.29 & 0.18 & 0.14 & 0.1 & 0.08 & 0.08 & 0.04 & 0.02 & <0.001\end{array}$ 
Table 2

\begin{tabular}{ccccccc}
\hline $\begin{array}{c}\text { Ageing Heat } \\
\text { Treatment }\end{array}$ & $\begin{array}{c}\text { \# of TEM } \\
\text { foil } \\
\text { observed }\end{array}$ & $\begin{array}{c}\text { \# of } \\
\text { grains } \\
\text { observed }\end{array}$ & $\begin{array}{c}\text { \# of } \\
\text { precipitates } \\
\text { measured }\end{array}$ & $\begin{array}{c}\text { Mean } \gamma^{\prime} \\
\text { diameter } \\
(\mathbf{n m})\end{array}$ & $\begin{array}{c}\gamma^{\prime} \text { Volume } \\
\text { fraction } \\
\text { (\%) }\end{array}$ & $\begin{array}{c}\gamma^{\prime} \\
\text { density } \\
\left(\boldsymbol{m}^{-5}\right)\end{array}$ \\
\hline & & & & & & \\
$670^{\circ} \mathrm{C}$ for $50 \mathrm{~h}$. & 1 & 3 & 192 & 4.6 & 0.8 & $1.6 \times 10^{23}$ \\
$670^{\circ} \mathrm{C}$ for $100 \mathrm{~h}$ & 1 & 3 & 271 & 6.2 & 2.5 & $2 \times 10^{23}$ \\
$720^{\circ} \mathrm{C}$ for $5 \mathrm{~h}$ & 1 & 4 & 465 & 6.4 & 2.4 & $9.3 \times 10^{22}$ \\
$720^{\circ} \mathrm{C}$ for $16 \mathrm{~h}$ & 1 & 5 & 1066 & 9.6 & 3.9 & $8.5 \times 10^{22}$ \\
$720^{\circ} \mathrm{C}$ for $24 \mathrm{~h}$ & 1 & 3 & 246 & 7.2 & 2.6 & $1.3 \times 10^{23}$ \\
$720^{\circ} \mathrm{C}$ for $100 \mathrm{~h}$ & 1 & 5 & 427 & 7.6 & 3.3 & $1.4 \times 10^{23}$ \\
\hline
\end{tabular}


Table 3

\begin{tabular}{cccccc}
\hline $\begin{array}{c}\text { Ageing Heat } \\
\text { Treatment }\end{array}$ & $\begin{array}{c}\text { \# of TEM } \\
\text { foil observed }\end{array}$ & $\begin{array}{c}\text { \# of GB } \\
\text { observed }\end{array}$ & $\begin{array}{c}\text { \% of GB with } \\
\text { disc }\end{array}$ phase & $\begin{array}{c}\text { \% of GB with } \\
\text { platelets }\end{array}$ phase & $\begin{array}{c}\text { Total GB } \\
\text { with } \eta \text { phase (\%) }\end{array}$ \\
\hline & & & & & \\
$670^{\circ} \mathrm{C}$ for $24 \mathrm{~h}$. & 2 & 100 & 0 & 0 & 0 \\
$670^{\circ} \mathrm{C}$ for $50 \mathrm{~h}$. & 2 & 100 & 0 & 0 & 0 \\
$670^{\circ} \mathrm{C}$ for $100 \mathrm{~h}$. & 2 & 100 & 24 & 6 & 80 \\
$720^{\circ} \mathrm{C}$ for $5 \mathrm{~h}$. & 2 & 100 & 58 & 28 & 90 \\
$720^{\circ} \mathrm{C}$ for $16 \mathrm{~h}$. & 2 & 100 & 40 & 50 & 92 \\
$720^{\circ} \mathrm{C}$ for $24 \mathrm{~h}$. & 2 & 100 & 40 & 52 & 80 \\
$720^{\circ} \mathrm{C}$ for $100 \mathrm{~h}$. & 2 & 100 & 18 & 62 & \\
\hline
\end{tabular}


Table 4

\begin{tabular}{ccccc}
\hline $\begin{array}{c}\text { Ageing Heat } \\
\text { Treatment }\end{array}$ & $\begin{array}{c}\text { Mean } \gamma^{\prime} \\
\text { diameter } \\
(\mathbf{n m})\end{array}$ & $\begin{array}{c}\gamma^{\prime} \\
\text { density } \\
\left(\boldsymbol{m}^{-3}\right)\end{array}$ & $\begin{array}{c}\Delta \sigma(\mathbf{M P a}) \\
\text { from CERT tests } \\
\boldsymbol{a t ~} 360^{\circ} \mathbf{C}\end{array}$ & $\begin{array}{c}\gamma^{\prime} \\
\alpha \text { barrier } \\
\text { strength }\end{array}$ \\
\hline & & & & \\
$670^{\circ} \mathrm{C}$ for $50 \mathrm{~h}$ & 4.6 & $1.6 \times 10^{23}$ & 402 & 0.25 \\
$670^{\circ} \mathrm{C}$ for $100 \mathrm{~h}$ & 6.2 & $2 \times 10^{23}$ & 503 & 0.24 \\
$720^{\circ} \mathrm{C}$ for $16 \mathrm{~h}$ & 9.6 & $8.5 \times 10^{22}$ & 365 & 0.22 \\
$720^{\circ} \mathrm{C}$ for $100 \mathrm{~h}$ & 7.6 & $1.4 \times 10^{23}$ & 393 & 0.21 \\
\hline
\end{tabular}


Table 5

\begin{tabular}{cccccc}
\hline $\begin{array}{c}\text { Ageing Heat } \\
\text { Treatment }\end{array}$ & $\begin{array}{c}\text { Test } \\
\text { Temperature }\left({ }^{\circ} \mathbf{C}\right)\end{array}$ & $\begin{array}{c}\text { YS } \\
(\mathbf{M P a})\end{array}$ & $\begin{array}{c}\text { UTS } \\
(\mathbf{M P a})\end{array}$ & $\begin{array}{c}\text { Strain to } \\
\text { failure (\%) }\end{array}$ & $\begin{array}{c}\text { \% brittle TG and IG cracking } \\
\text { on fracture surface }\end{array}$ \\
\hline & & & & & \\
$670^{\circ} \mathrm{C}$ for $24 \mathrm{~h}$. & 320 & 558 & 917 & 26 & 0 \\
$670^{\circ} \mathrm{C}$ for $50 \mathrm{~h}$. & 320 & 665 & 1032 & 22 & 9 \\
$670^{\circ} \mathrm{C}$ for $24 \mathrm{~h}$. & 360 & 570 & 937 & 23 & 3 \\
$670^{\circ} \mathrm{C}$ for $50 \mathrm{~h}$. & 360 & 675 & 978 & 14 & 19.5 \\
$670^{\circ} \mathrm{C}$ for $100 \mathrm{~h}$. & 360 & 776 & 936 & 6.5 & 9 \\
$720^{\circ} \mathrm{C}$ for $16 \mathrm{~h}$. & 360 & 638 & 993 & 17 & 11 \\
$720^{\circ} \mathrm{C}$ for $100 \mathrm{~h}$. & 360 & 670 & 912 & 12.5 & \\
\hline
\end{tabular}


Table 6

\begin{tabular}{cccc}
\hline $\begin{array}{c}\text { Ageing Heat } \\
\text { Treatment }\end{array}$ & $\begin{array}{c}\text { Test } \\
\text { Temperature }\left({ }^{\circ} \mathrm{C}\right)\end{array}$ & $\begin{array}{c}\text { Total crack length } \\
\text { on side surface }(\boldsymbol{\mu m})\end{array}$ & $\begin{array}{c}\text { Total crack length on side surface } \\
\text { /strain to failure }(\boldsymbol{\mu m} / \%)\end{array}$ \\
\hline & & & \\
$670^{\circ} \mathrm{C}$ for $24 \mathrm{~h}$. & 320 & 0 & 0 \\
$670^{\circ} \mathrm{C}$ for $50 \mathrm{~h}$. & 320 & 9225 & 419 \\
$670^{\circ} \mathrm{C}$ for $24 \mathrm{~h}$. & 360 & 1250 & 54 \\
$670^{\circ} \mathrm{C}$ for $50 \mathrm{~h}$. & 360 & 5243 & 374 \\
$670^{\circ} \mathrm{C}$ for $100 \mathrm{~h}$. & 360 & 15108 & 2324 \\
$720^{\circ} \mathrm{C}$ for $16 \mathrm{~h}$. & 360 & 702 & 41 \\
$720^{\circ} \mathrm{C}$ for $100 \mathrm{~h}$. & 360 & 9792 & 793 \\
\hline
\end{tabular}




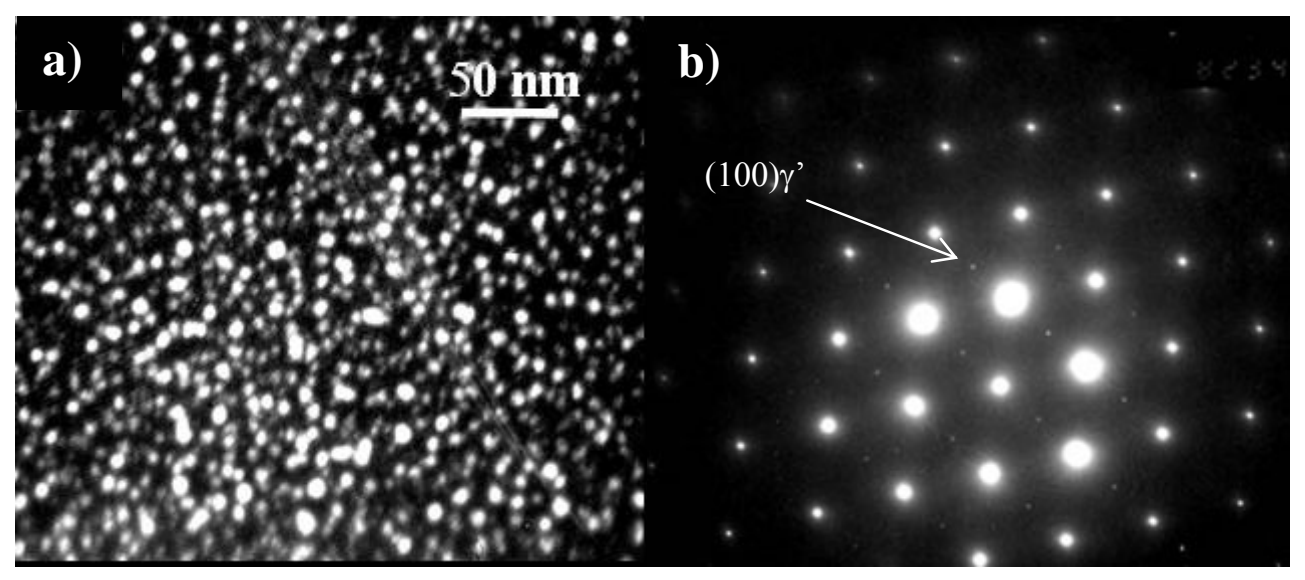

Figure 1 

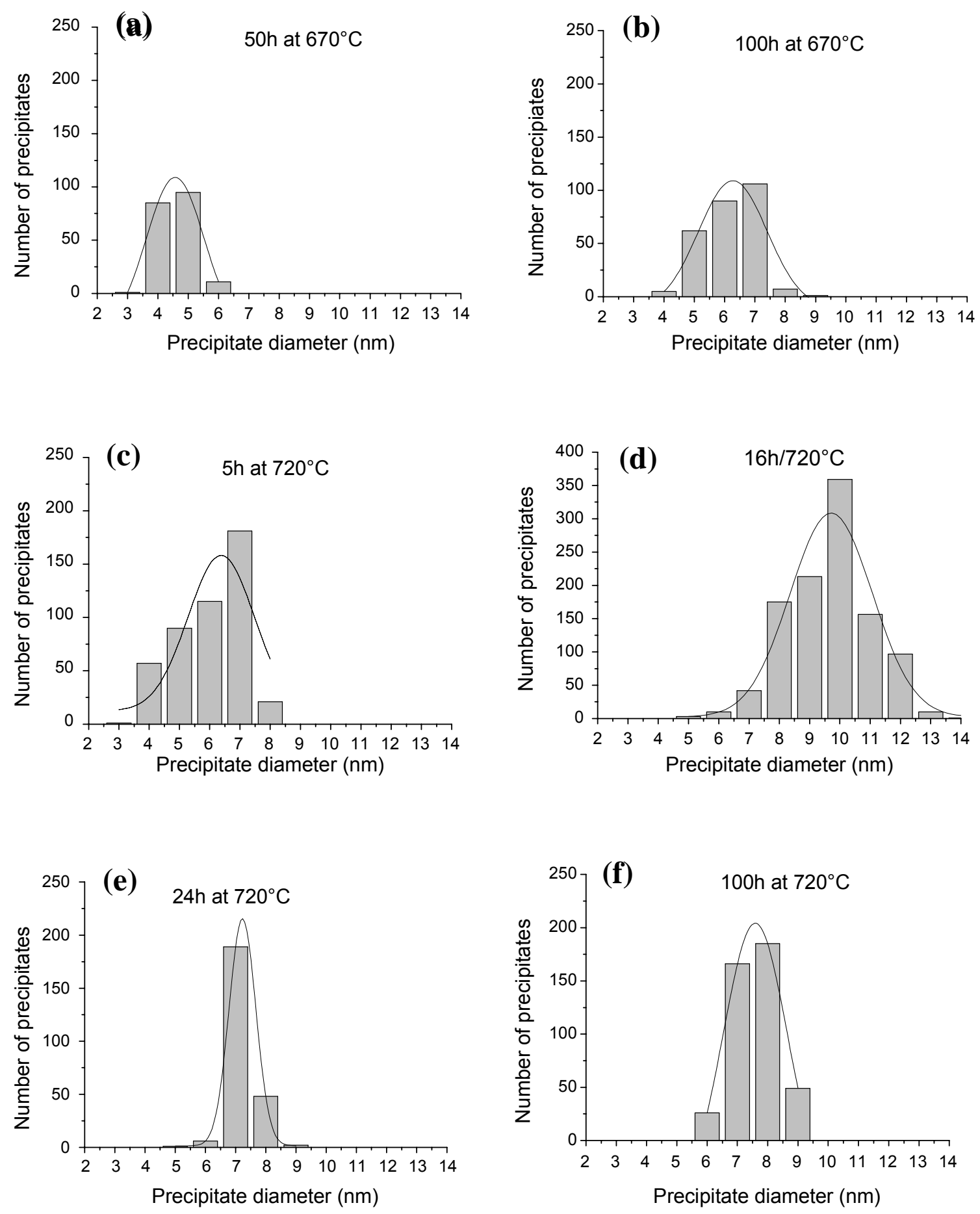

Figure 2 


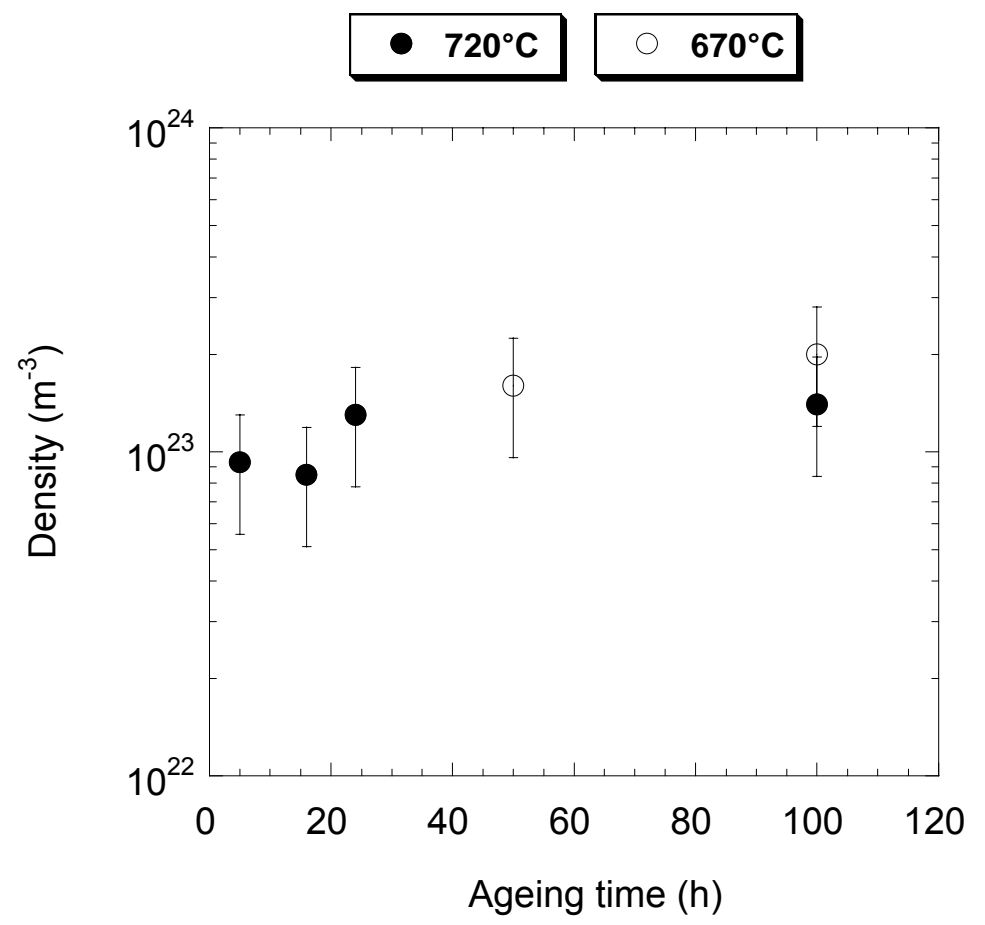

Figure 3 


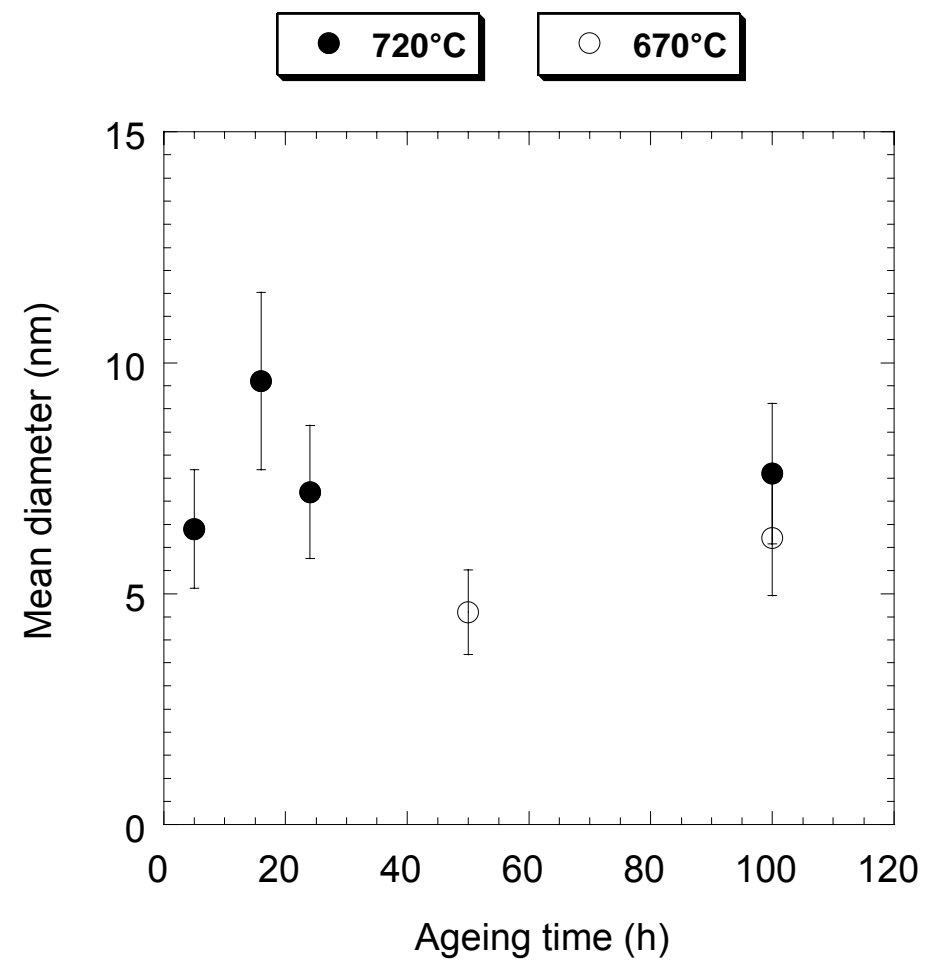

Figure 4 


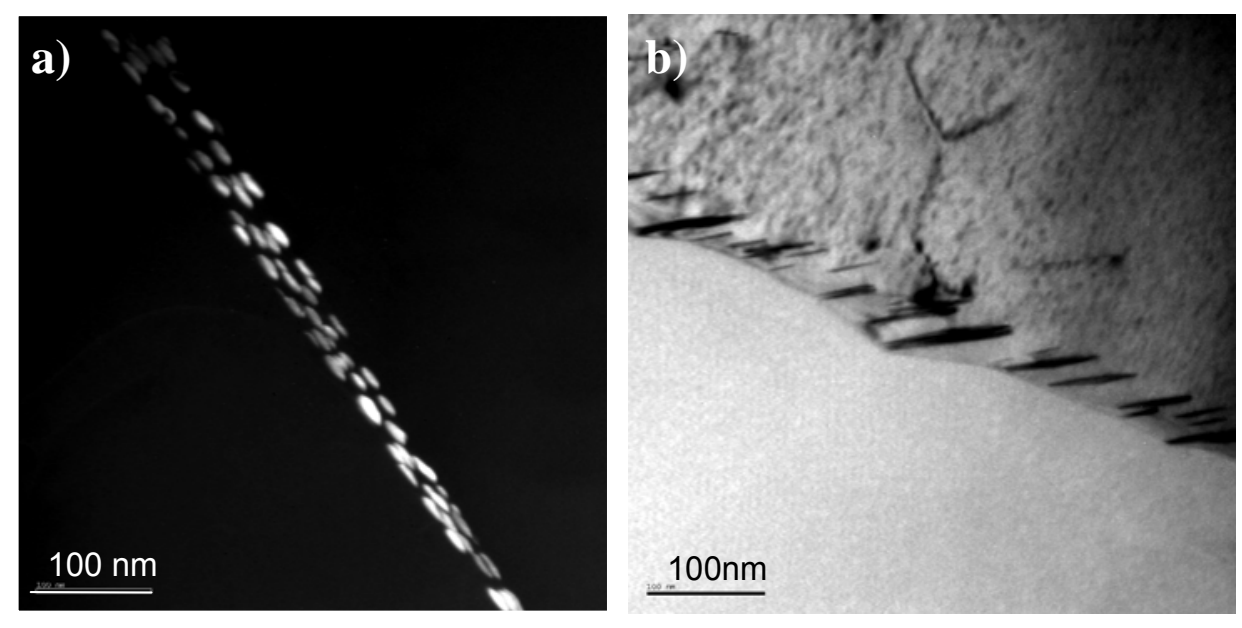

Figure 5 


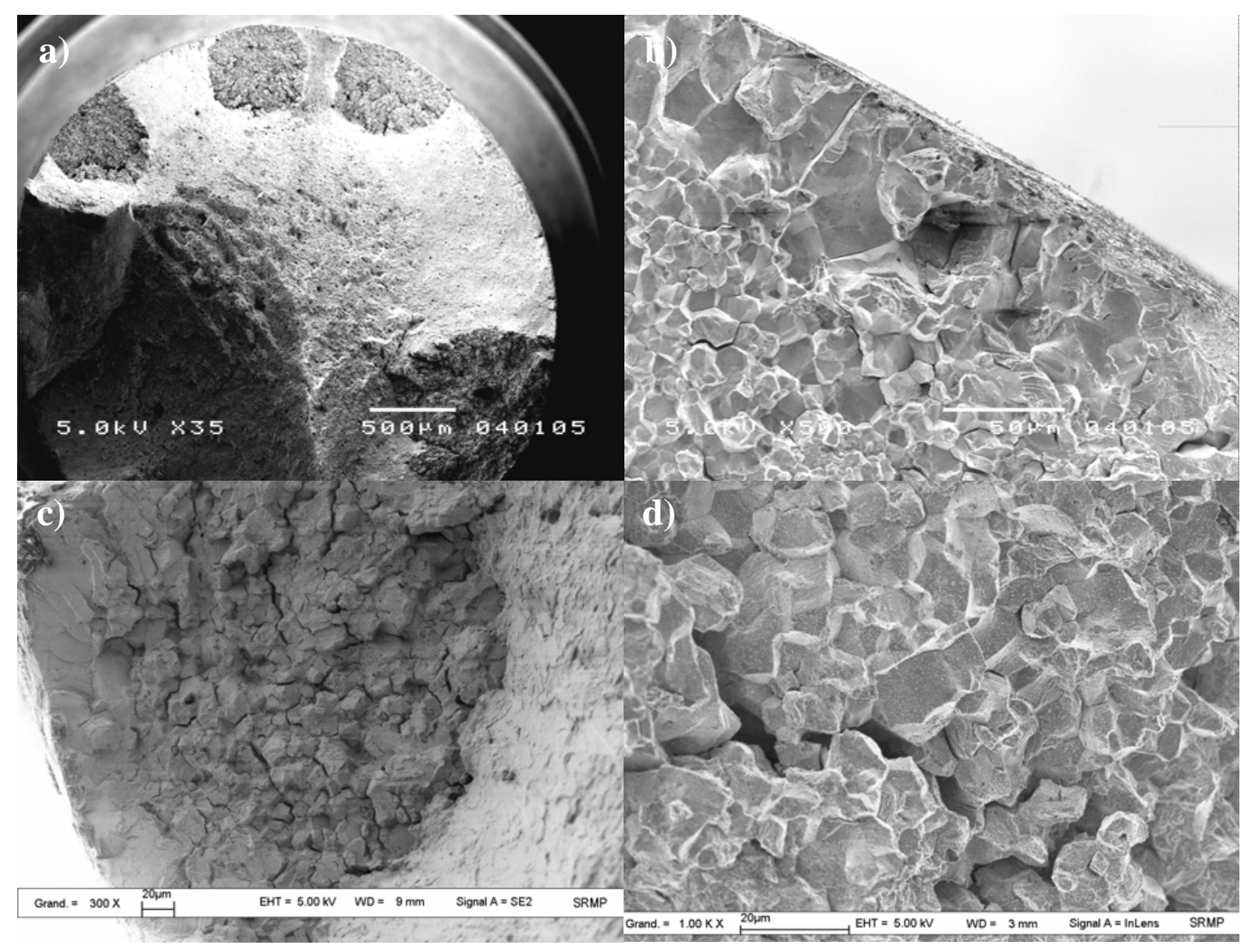

Figure 6 


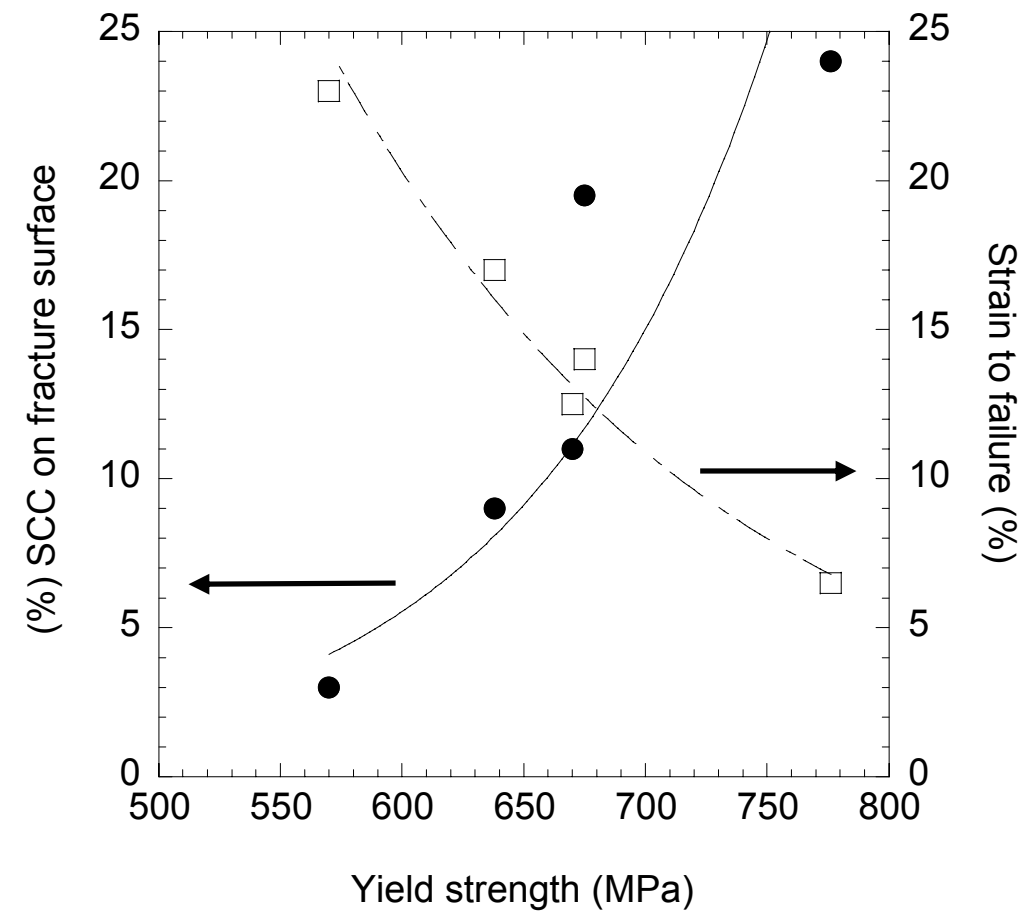

Figure 7 


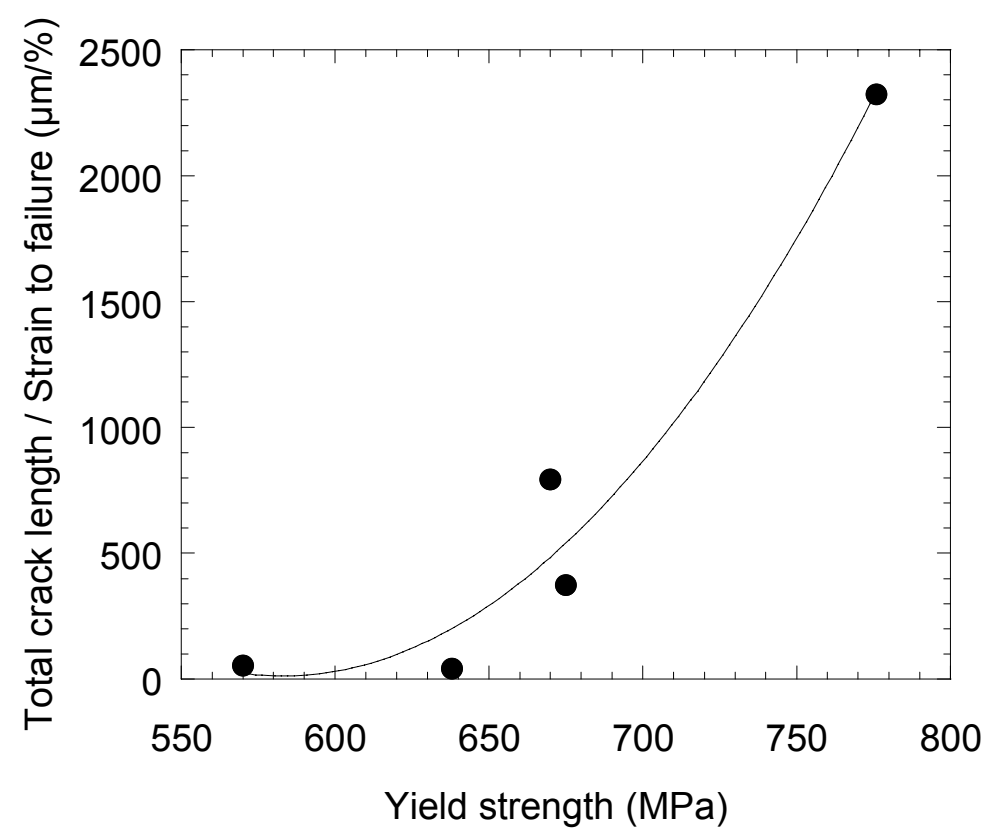

Figure 8 